\title{
Serum leptin concentration during puberty in healthy non-obese adolescents
}

C.M.A. Brandão, M.T. Lombardi, S.K. Nishida, O.M. Hauache and J.G.H. Vieira
Disciplina de Endocrinologia, Escola Paulista de Medicina, Universidade Federal de São Paulo, São Paulo, SP, Brasil
Correspondence

C.M.A. Brandão

R. Cincinato Braga, 282

01333-910 São Paulo, SP

Brasil

E-mail:

cynthia.brandao@fleury.com.br

Publication supported by FAPESP

Received June 13, 2002

Accepted June 6, 2003

\begin{abstract}
Data obtained during the past five years have indicated that there are important age- and gender-based differences in the regulation and action of leptin in humans. To study the physiological changes of leptin during puberty in both sexes, and its relationship with body composition and sexual maturation, we measured leptin concentrations in 175 healthy adolescents ( 80 girls, 95 boys, 10-18 years of age), representing all pubertal stages. We excluded individuals with a body mass index (BMI) below the 5 th or above the 95 th percentile relative to age. Serum concentrations of leptin were determined by a monoclonal antibody-based immunofluorimetric assay, developed in our laboratory. Body composition was determined by dual-energy X-ray absorptiometry. Pubertal stage was assigned by physical examination, according to Tanner criteria for breast development in females and genital development in males. Leptin concentration in girls $(\mathrm{N}=80)$ presented a positive linear correlation with age $(\mathrm{r}=0.35, \mathrm{P}=0.0012)$, BMI $(r=0.65, \mathrm{P}<0.0001)$ and $\%$ fat mass $(\mathrm{r}=0.76, \mathrm{P}<0.0001)$. In boys $(\mathrm{N}=95)$ there was a positive correlation with $\mathrm{BMI}(\mathrm{r}=0.49, \mathrm{P}<$ $0.0001)$ and $\%$ fat mass $(\mathrm{r}=0.85, \mathrm{P}<0.0001)$, but a significant negative linear correlation with Tanner stage $(\mathrm{r}=-0.45, \mathrm{P}<0.0001)$ and age $(\mathrm{r}=-0.40, \mathrm{P}<0.0001)$. The regression equation revealed that $\%$ fat mass and BMI are the best parameters to be used to estimate leptin levels in both sexes. Thus, the normal reference ranges for circulating leptin during adolescence should be constructed according to $\mathrm{BMI}$ or \% fat mass to assure a correct evaluation.
\end{abstract}

Leptin is an adipocyte-derived peptide hormone that interacts with the central nervous system. Serum leptin levels increase with progressive obesity in both men and women (1-3), but for any given measure of obesity, leptin levels are higher in women than in men $(4,5)$. Sexual dimorphism in circulating leptin concentrations is not observed during childhood or early puberty,
Key words - Leptin

- Pubertal development

- Body composition but is evident in later puberty, suggesting a relationship between leptin and gonadal steroids, body fat mass, body mass index (BMI) and other anthropometric parameters (6-13).

A threshold level of body fat has been recognized as necessary for the initiation of puberty and for maintenance of fertility in women (14). Leptin is probably the mediator between fat mass, or energy storage, and the 
hypothalamic-pituitary-gonadal axis in humans. In female mice, investigators have disclosed that leptin initiates sexual development and reproductive function (15-17).

In order to investigate the correlation between leptin levels and the anthropometric and pubertal changes observed during puberty, mainly the alterations of fat mass, we examined body composition by dualenergy X-ray absorptiometry (DEXA), anthropometry and leptin concentrations in a cross-sectional study of healthy adolescents of both sexes, at Tanner stages I to V.

The study included 175 students, 95 males and 80 females from a private school in São Paulo, SP, Brazil, ranging in age from 10 to 18 years, all in good health. The sample was highly representative of the great miscegenation observed in southeastern Brazil. None of the subjects was taking any medication or had any evidence of chronic disease. Anthropometric data and pubertal stage, according to Tanner criteria for breast development in females and genital stage in males, were assigned by two pediatricians. Subject endocrine and anthropometric characteristics are presented in Table 1. The subjects with BMI (weight in kilograms divided by

Table 1. Clinical characteristics and leptin levels of the male and female adolescents studied.

\begin{tabular}{llccrrr}
\hline & Sex & Mean & SD & Median & Minimum & Maximum \\
\hline Leptin (ng/ml) & Female & 8.538 & 7.674 & 6.0 & 1.0 & 51.0 \\
& Male & 3.632 & 4.265 & 2.0 & 1.0 & 22.0 \\
Age (years) & Female & 11.6250 & 1.5457 & 11.0 & 10.0 & 16.0 \\
& Male & 12.9368 & 1.9883 & 13.0 & 10.0 & 18.0 \\
BMI (kg/m²) & Female & 20.0375 & 4.1045 & 19.0 & 14.0 & 35.0 \\
& Male & 20.600 & 3.4898 & 20.0 & 14.0 & 31.0 \\
Weight $(\mathrm{kg})$ & Female & 46.0875 & 12.0707 & 45.0 & 26.0 & 85.0 \\
& Male & 53.8526 & 13.0376 & 55.0 & 24.0 & 86.0 \\
Height (cm) & Female & 151.4250 & 7.6237 & 152.0 & 131.0 & 168.0 \\
& Male & 160.8211 & 13.4417 & 162.0 & 123.0 & 188.0 \\
Fat mass (\%) & Female & 28.6625 & 6.8657 & 28.0 & 16.0 & 46.0 \\
& Male & 20.000 & 8.0371 & 17.0 & 9.0 & 41.0 \\
\hline
\end{tabular}

$\mathrm{BMI}=$ Body mass index the square of the height in meters) lower than the 5th and higher than the 95th percentiles were excluded, to guarantee that the sample consisted of individuals in good health and to exclude obesity as defined by the WHO. Reference data were obtained from Must et al. (18). A fasting blood sample was collected from each subject and the serum was frozen at $-70^{\circ}$ until analysis. Body composition was determined by DEXA, using a Hologic model 4500-A apparatus (Hologic, Inc., Waltham, MA, USA). The coefficient of variation for \%fat mass in our laboratory is $3.0 \%$.

Informed consent was obtained from the parents of all subjects, and from the subjects themselves. The research protocol was approved by the Hospital Ethics Committee.

We developed a sensitive immunofluorimetric assay for the measurement of serum leptin (19). Intra-assay precision was 3.1\% for a sample with a mean value of $8.6 \mathrm{ng} / \mathrm{ml}$ and $1.4 \%$ for a sample with a mean value of $12.8 \mathrm{ng} / \mathrm{ml}(\mathrm{N}=18)$. Interassay precision was $7.3 \%$ for a sample with a mean value of $3.5 \mathrm{ng} / \mathrm{ml}$ and $11.4 \%$ for a sample with a mean value of $10.5 \mathrm{ng} / \mathrm{ml}(\mathrm{N}=10)$. Twentythree samples were measured using our assay and the commercial immunoradiometric kit from DSL (Webster, TX, USA) and the difference between the values obtained (35.9 \pm 32.05 and $32.89 \pm 29.2 \mathrm{ng} / \mathrm{ml}$ ) were not statistically significant $(\mathrm{P}=0.33)$.

The relations between continuous variables were evaluated by the Spearman correlation coefficient. Multiple stepwise linear regression was used to determine the simultaneous contributions of each variable to serum leptin concentration. Between-group comparisons were made by the KruskalWallis test. $\mathrm{P}<0.05$ was considered significant (Graph Pad Prism, version 3.0; SPSS for Windows, version 8.0).

For both sexes, a strong relationship was observed between leptin levels and BMI or $\%$ fat mass determined by DEXA at all Tanner stages. In an age-related analysis, leptin 
levels in girls $(\mathrm{N}=80)$ rose from 10 to 18 years $(\mathrm{r}=0.35, \mathrm{P}<0.0012)$, in parallel to body weight $(\mathrm{r}=0.67, \mathrm{P}<0.0001)$ and $\mathrm{BMI}$ $(r=0.65, P<0.0001)$. The \%fat mass showed the strongest correlation with leptin levels $(\mathrm{r}=0.76, \mathrm{P}<0.0001)$. The mean serum leptin concentration was $7.15 \pm 7.03 \mathrm{ng} / \mathrm{ml}$ in prepubertal girls (Tanner I), $7.91 \pm 9.18$ $\mathrm{ng} / \mathrm{ml}$ in early pubertal girls (Tanner II and III), and $9.78 \pm 5.97 \mathrm{ng} / \mathrm{ml}$ in advanced pubertal girls (Tanner IV and V), with no statistically significant difference between them ( $\mathrm{P}=0.068$, Kruskal-Wallis), as suggested by the weak positive correlation between leptin and pubertal Tanner stage $(\mathrm{r}=0.28, \mathrm{P}<0094)$.

In contrast, in boys $(\mathrm{N}=95)$, circulating leptin levels decreased from Tanner I to $\mathrm{V}$ $(\mathrm{r}=-0.45, \mathrm{P}<0.0001$; mean value of $5.13 \pm$ $4.61 \mathrm{ng} / \mathrm{ml}$ in prepubertal boys, $3.65 \pm 4.51$ $\mathrm{ng} / \mathrm{ml}$ in early pubertal boys, and $2.23 \pm 2.31$ $\mathrm{ng} / \mathrm{ml}$ in late pubertal boys), although the mean values for each group of Tanner stage did not show significant differences ( $\mathrm{P}=$ 0.143 , Kruskal-Wallis test). Again, adiposity (\%fat mass) presented the closest correlation $(\mathrm{r}=0.85, \mathrm{P}<0.0001)$ with leptin levels. In boys, leptin concentration was negatively correlated with age $(r=-0.40, P<0.0001)$. As \%fat mass decreased through puberty in boys, serum leptin levels also fell in an agerelated manner.

Multiple stepwise linear regression for both sexes showed that weight, height, age and pubertal development had weak effects on leptin concentration while a greater proportion of variance in leptin concentration was explained by BMI, \%fat mass and gender.

Since BMI proved to be the major influencing variable, which was much easier to determine than \%fat mass for clinical purposes, we constructed reference ranges for leptin concentrations according to BMI ranges $(14-18,19-23$ and $>24)$ using the regression line stratified by sex (Figure 1). Statistical analysis (Kruskal-Wallis) showed a significant difference between BMI ranges.

The results of the present study confirm data reported by others (2-8) showing the presence of a significant sexual dimorphism in circulating leptin concentrations during puberty. We also observed that circulating leptin concentrations correlated positively with measures of obesity, including BMI and percent body fat in both sexes. However, as boys and girls present different changes in body composition during puberty, leptin levels reflected these gender differences.

We observed that \%fat mass increased through puberty in girls in parallel to BMI, even in a normal weight population, and leptin levels were higher at the end of pubertal development, probably as a consequence of this change in body composition. In boys, on the other hand, serum leptin concentrations present a discrete slope during adolescence, as \%fat mass decreases and the lean mass increases. For the same BMI value, the boys with a higher \%fat mass present higher leptin levels than those with lower percentiles.

Many investigators postulate that estradiol has a stimulatory effect on leptin concentration in males, while testosterone has a suppressive effect $(11,15)$. Wabitsch et al. (16) reported that testosterone or dihydrotestosterone promotes a significant decline in rates of leptin messenger RNA expression by adipocytes in vitro.

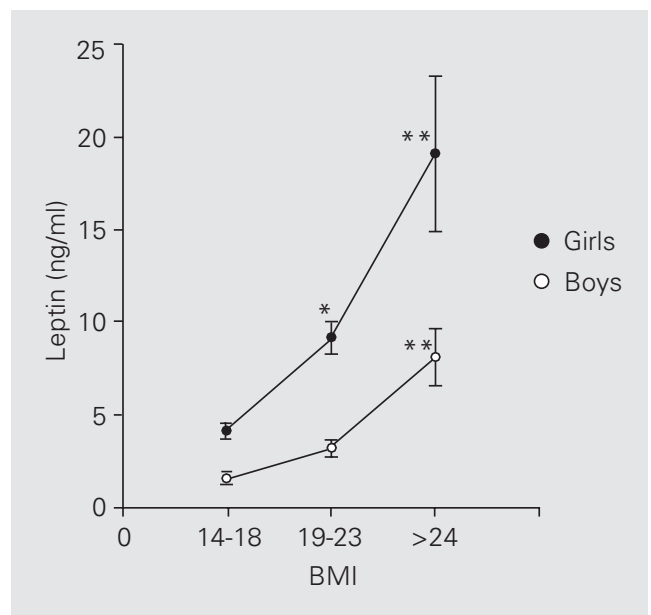

Figure 1. Mean serum leptin levels and $95 \%$ confidence interval for 95 male and 80 female adolescents stratified by body mass index (BMI) ranges $(14-18,19$ $23,>24) .{ }^{*} P<0.05$ compared to subjects in smaller $\mathrm{BMI}$ ranges and ${ }^{*} P<0.001$ compared to the first group, with BMI between 14-18 (Kruskal-Wallis test). 
Horlick et al. (13), in a very detailed study about the effect of puberty on circulating leptin, evaluated body composition by DEXA and measured estradiol and testosterone levels in a group of children and adolescents. Using multivariate regression analysis, they demonstrated a persistent gender difference in leptin levels even when adjusted for differences in testosterone, estradiol and \%fat mass, indicating that other metabolic or hormonal sex-related variables can influence leptin production. However, the modulation of leptin production and release by other factors such as insulin (2), growth hormone, insulin-like growth factor 1 or glucocorticoids has not been well established in literature.

Since leptin levels show a significant gender difference, especially in late puberty, and are closely related to BMI and adiposity, it is clear that normal reference ranges for leptin in the adolescent population should be constructed according to BMI or \% fat mass to assure a correct evaluation.

\section{References}

1. Considine RV, Sinha MK, Heiman ML et al. (1996). Serum immunoreactive-leptin concentrations in normal weight and obese humans. New England Journal of Medicine, 334: 292-295.

2. Kennedy A, Gettys TW, Watson P, Wallace P, Ganaway E, Pan Q \& Garvey $T$ (1997). The metabolic significance of leptin in humans: gender-based differences in relationship to adiposity, insulin sensitivity and energy expenditure. Journal of Clinical Endocrinology and Metabolism, 82: 1293-1300.

3. Isidori AM, Strollo F, Morè M, Caprio M, Aversa A, Moretti C, Frajese G, Riondino G \& Fabri A (2000). Leptin and aging: correlation with endocrine changes in male and female healthy adult populations of different body weights. Journal of Clinical Endocrinology and Metabolism, 85: 1954-1962.

4. Saad MF, Damani S, Gingerich RL, Riad-Gabriel MG, Khan A, Boyadjian R, Jinagouda SD, El-Tawil K, Rude RK \& Kamdar V (1997). Sexual dimorphism in plasma leptin concentration. Journal of Clinical Endocrinology and Metabolism, 82: 579-584.

5. Licinio J, Negrão AB, Mantzoros C et al. (1998). Sex differences in circulating human leptin pulse amplitude: clinical implications. Journal of Clinical Endocrinology and Metabolism, 83: 4140-4147.

6. Carlsson B, Ankarberg C, Rosberg S, Norjavaara E, AlbertssonWikland K \& Carlsson LMS (1997). Serum leptin concentrations in relation to pubertal development. Archives of Disease in Childhood, 77: 396-400

7. Clayton PE, Gill MS, Hall CM, Tillmann V, Whatmore AJ \& Price DA (1997). Serum leptin through childhood and adolescence. Clinical Endocrinology, 46: 727-733.

8. Blum WF, Englaro P, Hanitsch S et al. (1997). Plasma leptin levels in healthy children and adolescents: dependence on body mass index, body fat mass, gender, pubertal stage and testosterone. Journal of Clinical Endocrinology and Metabolism, 82: 2904-2910.

9. Garcia-Mayor RV, Andrade MA, Rios M, Lage M, Dieguez C \& Casanueva FF (1997). Serum leptin levels in normal children: relationship to age, gender, body mass index, pituitary-gonadal hormones and pubertal stage. Journal of Clinical Endocrinology and Metabolism, 82: 2849-2855.

10. Ahmed ML, Ong KK, Morrell DJ, Cox L, Drayer N, Perry L, Preece
MA \& Dunger DB (1999). Longitudinal study of leptin concentrations during puberty: sex differences and relationship to changes in body composition. Journal of Clinical Endocrinology and Metabolism, 84: 899-905.

11. Demerath EW, Towne B, Wisemandle W, Blangero J, Chumlea WC \& Siervogel RM (1999). Serum leptin concentration, body composition and gonadal hormones during puberty. International Journal of Obesity and Related Metabolic Disorders, 23: 678-685.

12. Kirel B, Dogruel N, Akgun N, Kilic FS, Tekin N \& Ucar B (1999). Serum leptin levels during childhood and adolescence: relationship with age, sex, adiposity and puberty. Turkish Journal of Pediatrics, 41: 447-455.

13. Horlick MB, Rosenbaum M, Nicolson M, Levine LS, Fedun B, Wang J, Pierson Jr RN \& Leibel RL (2000). Effect of puberty on the relationship between circulating leptin and body composition. Journal of Clinical Endocrinology and Metabolism, 85: 2509-2518.

14. Frisch RE (1994). The right weight: body fat, menarche and fertility. Proceedings of the Nutrition Society, 53: 113-129.

15. Chehab FF, Lim ME \& Lu R (1996). Correction of the sterility defect in homozygous obese female mice by treatment with human recombinant leptin. Nature Genetics, 12: 318-320.

16. Wabitsch M, Blum WF, Muche R, Braun M, Hube F, Rascher W, Heinze E, Teller W \& Hauner H (1997). Contribution of androgens to the gender difference in leptin production in obese children and adolescents. Journal of Clinical Investigation, 100: 808-813.

17. Chehab FF, Mounzih K, Lu R \& Lim ME (1997). Early onset of reproductive function in normal female mice treated with leptin. Science, 275: 88-90.

18. Must A, Dallal GE \& Dietz WH (1991). Reference data for obesity: 85th and 95th percentiles of body mass index (wt/ht2) and triceps skinfold thickness. American Journal of Clinical Nutrition, 53: 839846.

19. Vieira JGH, Hauache OM, Ghiringhello MT, Lombardi MT \& Nishida SK (2001). Development of a monoclonal antibody-based immunofluorometric assay (IFMA) for human leptin. Clinical Chemistry, 47 (Suppl): 5 (Abstract). 